\title{
The emergence of collectively owned self-supply water supply systems in rural South Africa - what can we learn from the Tshakhuma case in Limpopo?
}

\author{
Moritz Hofstetter ${ }^{1}$, Barbara van Koppen² and Alex Bolding ${ }^{3}$ \\ 'International Water Management Institute (IWMI), Guggistr. 23, 6005 Luzern, Switzerland \\ ${ }^{2}$ Poverty, Gender and Water, International Water Management Institute (IWMI), Private Bag X813, Silverton 0127, Pretoria, South Africa \\ ${ }^{3}$ Water Resources Management Group, Wageningen University, Droevendaalsesteeg 3, 6708PB Wageningen, The Netherlands
}

Despite the rapid extension of public service delivery since the end of Apartheid, many rural citizens in South Africa still rely on their own initiatives and infrastructure to access water. They construct, improve, operate and maintain infrastructure of different complexities, from individual wells to complex collectively owned water schemes. While most of these schemes operate without legal recognition, they provide essential services to many households. In this article we will first provide an overview of the growing international body of literature describing self-supply as an alternative pathway for public service delivery. We then take a historical perspective on the role of communities and self-supply in South Africa and describe the emergence of six collectively owned, gravity-fed, piped schemes in Tshakhuma, Limpopo Province. We describe and compare these systems using key characteristics like resource access, investment, construction, operation, maintenance and institutional governance. We further assess their performance with regard to coverage, service level, reliability, governance structure, accountability and water quality. We do so because we are convinced that lessons learned from studying such schemes as locally adapted prototypes have the potential to improve public approaches to service delivery. The described cases show the willingness of community members to engage with service delivery and their ability to provide services in cases where the state has failed. The assessment also highlights problematic aspects of self-supply related to a lack of accountability, technical expertise and the exclusion of disadvantaged community members. By describing and assessing the performance of rural self-supply schemes, we aim to recognize, study and learn from such schemes. We consequently do not conclude this article by providing answers, but by raising some pertinent, policy-relevant questions.

\section{INTRODUCTION}

\section{South Africa's water services challenge}

In 1994, the incumbent democratically elected government of South Africa was facing enormous racial and regional inequalities in access to water services. Huge efforts have been undertaken since then to extend service delivery for domestic uses to previously unserved groups. This campaign was successful and resulted in an extension of the total population served by improved water sources from 64\% in 1994 (Muller et al., 2017) to 85.5\% in 2017 (Stats SA, 2019). However, this progress was mainly achieved in urban areas, while $24 \%$ of the rural households are still relying on 'unimproved' water sources like unprotected wells, rainwater harvesting, surface water bodies, bottled water or tanker trucks (Stats SA, 2017). Moreover, the household survey of 2016 showed that $31.4 \%$ of the rural population with access to piped water experienced water interruptions of more than 14 days during the previous 3 months, compared to $4.7 \%$ of the served population in metros (Stats SA, 2017). This points to the operation and maintenance challenges besetting especially rural water infrastructure. The latter is also borne out by the meagre $36.4 \%$ of the total population of Limpopo Province that perceives their water service quality as good, despite a coverage of $74.7 \%$ with piped water supply in this province (Stats SA, 2019).

In this paper we will first provide an overview of the growing international body of literature describing self-supply as an alternative pathway for public service delivery. We then take a historical perspective on the role of communities in self-supply in South Africa and describe the emergence of six collectively owned, gravity-fed, piped schemes in Tshakhuma, Limpopo Province. We describe and compare these systems on key characteristics like resource access, investment, construction, operation and maintenance $(\mathrm{O} \& \mathrm{M})$ and institutional governance. We further assess their performance with regard to coverage, service level, reliability, governance, accountability and water quality.

Thus, we hope to contribute to an awareness of what communities are capable of and to filling the knowledge gap on such initiatives. We do not imply that user-owned schemes or supported selfsupply represent a solution for the challenges in rural water supply, nor that the aim of policy makers should be to reproduce such schemes elsewhere. We are convinced though, that if these schemes are studied as locally adapted prototypes of water service delivery solutions, lessons can be learned to combine the strengths of communities and municipalities in public service delivery. Finally, we raise additional questions and points of interest for further research.

\section{CORRESPONDENCE}

Moritz Hofstetter

EMAIL

mor.hofstetter@gmail.com

\section{DATES}

Received: 1 September 2019

Accepted: 25 March 2021

\section{KEYWORDS}

service delivery collectively owned community-led accountability infrastructure

\section{COPYRIGHT}

(c) The Author(s) Published under a Creative Commons Attribution 4.0 International Licence (CC BY 4.0) 


\section{The international interest in self-supply}

The most comprehensive definition of self-supply in the WASH sector comes from Sutton and Butterworth (2021 p. 28), who define it 'as the construction of, or incremental improvement to water supplies and sanitation by households and small groups, largely using their own means.' It is also suggested that self-supply schemes can be supported by outside actors (Olschewski et al., 2017; Sutton and Butterworth, 2021; Butterworth et al., 2013). While such schemes have existed since time immemorial, they have only recently caught the attention of international scholars, NGOs and governments (WHO, 2017; Sutton and Butterworth, 2021).

Scholars attribute two main advantages to supported self-supply as an approach to service delivery. The first point is the suggested higher sustainability of the infrastructure due to co- or full ownership (Olschewski et al., 2016, 2017; Sutton et al., 2004; Pump Aid, 2016; Maltha and Veldman, 2016; Cranfield University, Aguaconsult, IRC 2006) and simpler and more affordable technology used (Maltha and Veldman, 2016; Sutton et al., 2004). The second advantage is the supposed lower cost of service extension due to the user investments (Olschewski et al., 2017, Sutton, 2007, 2004; Butterworth et al., 2014; GLOWS, 2012; Sutton, 2018).

In the irrigation sector, it has been widely recognised that coownership by users of infrastructure improves its sustainability (Marks and Davis, 2012; Yacoob, 1990; Boelens and Vos, 2014; Coward, 1986a, b). This effect has also been shown in rural water and sanitation schemes (Manikutty, 1997; Sutton and Butterworth 2021). While reliable data for user investments are hard to obtain, calculations of the World Health Organisation (WHO) for seven developing countries suggest that investments in self-supply by households amount to a substantial share of total investments in WASH services. In Ghana, for example, such investments by households were estimated to reach $69 \%$ of total investments into the WASH sector in 2014 (WHO, 2017).

The perspective of expanding water services to rural communities at much lower cost for the government and in a more sustainable manner has induced a number of governments to introduce policies and programmes to support such self-supply. Ethiopia has introduced national policy guidelines on self-supply, which include a $50 \%$ subsidy for collectively owned self-supply projects (Federal Democratic Republic of Ethiopia, 2012) and Sierra Leone's Rural Water Supply Strategy includes self-supply as an official service delivery approach (Sierra Leone, 2013 as cited in Gelhard, 2014). The governments of Zimbabwe (Olschewski et al., 2016), Uganda (Kyeyune et al., 2011), Benin and Zambia (Sutton et al., 2004) supported projects or have launched pilots to evaluate the potential of this approach. Sutton and Butterworth (2021) recently published a book on the topic and there is a growing body of peer-reviewed literature describing 'self-supply systems' in Ghana (Grönwall, 2016), Nigeria (Oluwasanya et al., 2011), Madagascar (MacCarthy et al., 2013), Ethiopia (Butterworth et al., 2013), Kenya, and Finland (Arvonen et al., 2017), and reports from Sierra Leone (Gelhard, 2014), Mali (Maiga et al., 2006), Cameroon (Njoh, 2009), Ghana (Nyarko et al., 2010) Uganda (Carter, 2006) and Kenya (Advani, 2010).

\section{Self-supply and the role of communities in water service delivery in South Africa}

While the first public investments in water services date back to 1811 , when British settlers in Cape Town constructed the first public reservoir to supply a growing number of fountains (Burman, 1969 as cited in Juuti et al., 2007), such initiatives focused for a long time solely on urban areas like Durban, Johannesburg and Grahamstown (Mäki, 2007). The lack of public services in the vast rural areas of the country meant that self- supply was the norm. In many cases, this situation did not change until the end of Apartheid. While in 'white' apartheid South Africa, municipalities were responsible for water services (Muller et al., 2017), in the so called 'native reserves' or 'homelands' water services were provided by large homeland bureaucracies, which Eales earmarked to have 'poor productivity and corruption wellentrenched' (2011 p. 39). The provision of water services was strongly racialized (Marcatelli and Büscher, 2019), whereby the majority of the population did 'not have access to an adequate supply of safe water at a reasonable distance' (CSIR, 2020 p. 27).

With the end of apartheid, the government faced the challenge that there were no local municipalities in these former 'homelands' to roll out services to the most disadvantaged part of the population (Eales, 2011). The strategy of the then Department of Water Affairs and Forestry (DWAF) for areas without functional administrations was therefore to set up local water committees (LWCs) with the help of existing water boards. These LWCs would then ultimately be subsumed into local government structures once these were functional. It was a period of major capital investments into infrastructure expansion guided by the international best practice of community participation and demand-driven development (DWAF, 1994). To increase capacity, new implementing agent arrangements were drafted with non-governmental organisations (NGOs). NGOs like Mvula trust played a key role in contributing much needed know-how in community-driven development during this infrastructure roll-out (DWAF, 2004). This approach resulted in community-based organisations (CBOs) becoming pivotal in the operation and maintenance of rural water service infrastructure. ${ }^{1}$

With the introduction of new policies and the establishment of local municipalities, the role of community members in water service delivery started to change. The Water Services Act (1997) created the base for all further policies of the sector and established the legal concepts of both water service authorities ${ }^{2}$ (WSA) and water service providers ${ }^{3}$ (WSP). A WSA can act as a WSP through their own departments, enter a contractual agreement with a WSP or form a joint venture with another water service institution to provide services (RSA, 1997, section 19). Assigning an external WSP was, though, only permitted in case no public entity was able to provide the service. The Water Services Act further prohibited anyone from using 'water services from a source other than a WSP nominated by the WSA having jurisdiction in the area in question' (RSA, 1997, section 6). This new regulation rendered all existing community-based organisations and common selfsupply initiatives illegal, unless the municipalities would admit their failure and hand them the responsibilities. The Municipal Systems Act (MSA) (RSA, 2000) then established even more procedural hurdles for the recognition of CBOs as WSPs. The MSA classifies all non-public entities as external service provision mechanisms (sections 76 and 80 of the MSA). This meant that $\mathrm{CBO}$ in rural areas applying for legal recognition now had to go through the same procedure of competitive bidding (section 83 of the MSA) as a private company aiming to privatise service provision in a metropolitan area. These new regulations only became fully effective with the first local government elections in December 2000.

This regulatory push happened despite the considerable change in attitude towards CBOs within parts of the government, away from perceiving CBOs/LWCs as temporary solutions (DWAF, 1994), towards seeing them as a valuable partners in rural settings (DWAF, 2000 a, b, c, d; RSA, 1998a; DPLG, 2000). It was officially argued that these new policies would set the norms and standards (RSA, 1997) to allow for affordable service delivery and universal access (RSA, 2000), but during the interviews for this study, interviewees raised three additional motivations for these new regulations. 
Firstly, some policy makers considered community-based water service provision to be obsolete or, as a leading official of the Municipal Infrastructure Grant (MIG) put it: 'this was the way [to provide services] when there was no State to cater for the people. ${ }^{4}$ Secondly, labour unions were against any external water service provision out of fear for privatisation of services. ${ }^{5}$ Thirdly, and most often mentioned, was the absence of political will to allow community organisations to exist parallel to the newly formed local governments and compete with them for the responsibilities and financial resources related to water services. ${ }^{6}$

The new policy environment created a discrepancy between the legal recognition of the efforts and capacities of community members and their actual role in water service delivery. Local politicians and government officials perceive community members as consumers, ${ }^{7}$ whose role is to avoid vandalism and to save water ${ }^{8}$, to make it easy for the municipality to implement projects ${ }^{9}$ or to express their wishes in the consultations for the Integrated Development Plan $^{10}$ (IDP) ${ }^{11}$. The same community members construct, improve, operate and maintain water infrastructure and fill the gaps in public service delivery. These schemes vary in complexity, ranging from individual wells to collectively owned, piped water schemes. While every household has a right to access water for reasonable domestic uses, watering of animals and gardening for non-commercial purposes (RSA, 1998b) ${ }^{12}$, collective schemes that are not registered as WSPs are rendered illegal. Sector officials further raised concern with water quality and the lack of its monitoring in self-supply schemes. ${ }^{13}$ Yet, local governments in poorer and remoter districts pragmatically acknowledged the existence of such self-supply schemes (Sutton, 2004).

While self-supply is often associated with poor, black communities, it is a phenomenon that also occurs in middle and upper class, white settings in the form of rate payer associations or individual households going 'off-grid'. The formation of ratepayer associations is often the result of a conflict between municipalities and citizens over the level and quality of services provided. Ratepayers declare a dispute ${ }^{14}$ with the municipality and withhold their rate payments (May, 2004; Matebesi, 2017). According to the national taxpayer union, such disputes occurred in 42 municipalities in 2011 (National Treasury RSA, 2011). In extreme situations of service delivery failure, these associations can also create parallel structures and start to provide services themselves (National Treasury RSA, 2011; May, 2004), as was the case with water and sanitation services in Sannieshof (Matebesi, 2017; Gouws et al., 2010). Another form of self-supply among high-income households is to go off-grid by investing into alternative sources such as groundwater, rainwater or greywater. During the 'day zero' crisis in Cape Town, the demand for such technologies surged. At the same time the demand for water from public supplies was reduced from $1200 \mathrm{ML} /$ day (megalitres of water per day) in 2015, to $526 \mathrm{ML}$ /day in mid-February 2018, with especially large users reducing their consumption (Simpson et al., 2019). Since in the South African tariff system the consumers with high abstractions cross-subsidise the services to the poor (DWAF, 2002), this development created immense financial issues for the public service delivery of the City of Cape town (Simpson et al., 2019). At the same time some of the wealthiest households went off-grid and continued to use large quantities of water (Taing et al., 2019; Oomen, 2021).

\section{Conceptualizing self-supply systems as forms of prototyping}

Prototyping is a pathway to innovation that consciously operationalises the design principle of trial and error, allowing for adaptation and learning, in contrast to blueprint solutions. It has been asserted that such an approach to technology development can lead to more locally adapted and sustainable systems, as demonstrated by farmer-led irrigation developments (Nkoka et al., 2014). We consider the studied schemes as such prototypes of locally adapted water delivery systems in order to learn from them.

We first describe the schemes based on five key focus points: emergence; access conditions to the resource; investment and construction; operation and maintenance practices; and institutional solutions for governance. We then assess the strengths and weaknesses of these schemes by discussing three dimensions of their performance: coverage and service level; governance and accountability; water quality. These were selected based on evaluation manuals developed by Still and Balfour (2006) and Mvula Trust (2000).

\section{Five key dimensions for description \\ Emergence}

Many self-supply systems are initiated in response to a failure of public water supply, at the behest of one or a group of important figure(s) in the community. The origins of a self-supply scheme often determine access and governance conditions.

\section{Access conditions to the resource}

To describe the rules and regulations related to the access to water, we make use of legal pluralism and hydraulic property creation. Legal pluralism has been described by Meinzen-Dick and Pradhan (2001 p. 11) as 'the coexistence and interaction of multiple legal orders within a social setting or domain of social life'. According to Berman, conflict is unavoidable in situations with such overlapping legal systems (2007). Studying this is important, since the practice of establishing rights to access water is not only defined by a country's statutory legal framework, but also by non-official customary systems (Boelens and Vos, 2014; Von Benda-Beckmann, 2002) commonly applied in post-colonial settings of Africa (Merry, 1988; Pimentel, 2011). While this is key to understanding the creation of rights to access water in traditional contexts, it is sometimes interpreted as a threat to the power and rule-making capacity of national bureaucrats' (Boelens and Zwarteveen, 2005, p. 744). The theory of hydraulic property describes how, in farmer-led irrigation schemes, an investment not only creates ownership of infrastructure and the water conveyed, but also allows exclusion of non-investors (Coward, 1986a; Boelens and Doornbos, 2001; Komakech etal.,2012; Boelens and Vos, 2014).

\section{Investment and construction; operation and maintenance}

The process of planning and constructing infrastructure is not linear, but prone to deviations, constantly changing and adapting to its physical environment and its use (Sanchez et al., 2019). We consider the process of investing and constructing infrastructure to be a key step especially because the established ownership relationships form the basis for future collective action. Investment determines both the rights and obligations of users towards the operation and maintenance of collective works (Coward, 1986b).

\section{Institutional governance}

We build our analysis of the institutional aspects of these schemes on a critical institutionalist perception. Such an approach emphasizes the embeddedness of institutions in everyday social life and the complexity that this creates (Cleaver and De Koning, 2015). It challenges the assumption of mainstream institutionalists that human behaviour is exclusively guided by rational choice and that design principles, as the ones formulated by Ostrom (1993), can guide the crafting of sustainable institutions (Cleaver, 2017; Hall et al., 2014). Instead we apply an institutional bricolage framework, as introduced by Frances Cleaver (2001), that conceptualizes institutions as being reshaped or pieced together in a conscious 
or unconscious manner as a result of locally specific relationships, knowledge and previously existing institutional arrangements (Cleaver, 2001, 2002; De Koning, 2011, 2014; Cleaver, 2017). Taking such an approach acknowledges that institutions are shaped by power relations and people's complex social identities (Cleaver, 2017).

\section{Three-fold assessment of performance}

In order to assess these schemes, we identify three fields of interest:

\section{Coverage and service level}

Coverage refers here to the capacity of the scheme to provide water services to the households in its command area. This includes both an assessment of technical limitations and membership requirements that reduce coverage. The service level describes regularity and predictability of water supply to the member households.

\section{Governance and accountability}

In this section we assess the institutional arrangements of the schemes and how they influence the provision of the promised services. We choose accountability as a key concept. While conventional definitions of accountability focus on the relations among formal actors or formal actors and users (Dann and Sattelberger, 2015; World Bank, 2003), we focus here on informal forms of accountability that thrive on mutual norms and trust (Wit and Akinyoade, 2008). In this context where users are the (partial) owners of the infrastructure, we understand accountability as the strength of the established informal relations and their capacity to ensure the delivery of the promised services and providing pathways to respond to emergent performance-related issues.

\section{Water quality}

We compare the measures to secure or monitor water quality in the described schemes and how they relate to the national standards.

\section{METHODS}

This study is based on semi-structured interviews and an in-depth analysis of the international literature on self-supply and the South African water service policies. Interviews were conducted with 24 government officials from local to national level and 6 consultants operating in the water sector. To describe the collectively owned, piped self-supply schemes, additional semi-structured interviews were conducted with 7 local water committee members, 4 community infrastructure operators, 4 local traditional leaders and 64 randomly selected community members living within both the up- and downstream sections of the studied systems (43 using services of one of the schemes and 21 relying on other sources). The fieldwork was conducted between April 2017 and June 2018. During this time, the main author worked as a research consultant for the International Water Management Institute (IWMI) in an action research project, aiming to improve service delivery approaches for rural communities. ${ }^{15}$

\section{Case study setting}

Tshakhuma is a growing, rural-peri-urban village with over 4000 households, located in Makhado Municipality, Vhembe District, in Limpopo Province. Situated along a mountain ridge, it receives ample annual rainfall (average 2009-2018: $854 \mathrm{~mm}$; FAO, 2018) which feeds several springs and perennial streams, that allow for water abstraction above the village. Its location along the R524 between Makhado and Thohoyandou fostered the creation of a vibrant fruit market, where both produce from homestead production and the surrounding commercial farms is sold (Dagada et al., 2015). Van Koppen et al. (2020) found that 25\% of the households in Tshakhuma practise irrigated cultivation at their homestead for home consumption or commercial sale or both.

The former Venda homeland government finalised the construction of a public water supply scheme in 1990. This scheme is connected to a dam and provides water directly to the households (Van Koppen, 2017). At the time of the study, this scheme still provided water services to some sections of the village, while in other sections of the village the services had collapsed permanently. Moreover, the village has grown beyond the perimeter of the public scheme, so many new households have never been connected.

At the time of the research, 13 independent self-supply schemes existed within Tshakhuma village, of which six were selected for study based on the number of households served, their organisational form and the existence of monthly contributions (Table 1).

\section{Emergence}

In the absence of reliable public services, a group of community members in Rudanani Section attempted in the late 1990s to use furrows to supply water to households from springs located upstream of the village. This first attempt was not successful. In 2004, a retired official of the Department of Water Affairs became the first to lay a pipe to the same source. Once successful, many of his neighbours wanted to join and the matter was taken to the local traditional leader. ${ }^{16}$ It was decided that this should be a community project. A committee with 6 members was formed and 11 households contributed funds to buy pipes (see Fig. 1). By 2010, the system was supplying 39 households. The success of this small scheme triggered other sections to copy their effort. By 2016, 12 more schemes had been established. ${ }^{17}$

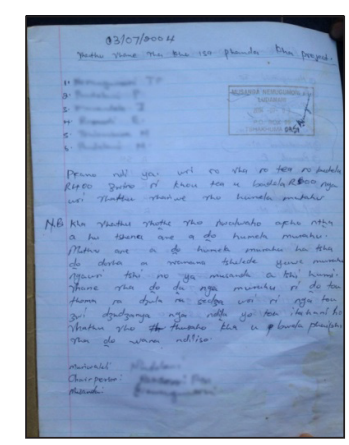

Figure 1. Excerpt from the notes of the traditional leader

Table 1. The six selected self-supply schemes of Tshakhuma

\begin{tabular}{lccc}
\hline & Households served & Form of organisation & Monthly payments \\
\hline Mulangapuma 1 & 113 & Communal \\
Mulangapuma 2 & 219 & Communal \\
Muhovoya & 236 & Private enterprise \\
Thondoni & 496 & Communal \\
Luvhalani & 43 & Communal \\
Rudanani & 20 & Communal \\
\hline
\end{tabular}




\section{Accessing water resources}

The relatively humid climate creates the possibility to abstract water above the village and divert it to the households using gravity. While each individual household has a right to this water based on the NWA (RSA, 1998b), the interviewees indicated the necessity to obtain the permission of the traditional leaders to access water and construct new infrastructure on their land..$^{18}$ This characterises a situation of legal pluralism.

In three schemes, the local headman hosted the first meeting where the idea was introduced to the community, while in another case the permission was obtained by informing the local headman. ${ }^{19}$ In the remaining two cases, the initiator either consulted the traditional leader individually, as there was no initial plan to extend the water pipe to other households, ${ }^{20}$ or started the scheme independently from the traditional leader, because the local headman had lost his moral authority in an unrelated incident. ${ }^{21}$ Once permission of the traditional leader was given and the connection installed, no one else could use the same source, unless earlier users would agree to this. This was manifested in the resolution of a conflict over the use of a source during the 2016 drought, when the original investor group was able to prove based on meeting notes that they had asked for permission to use a specific source and therefore had the exclusive right to its use. ${ }^{22}$

\section{Investment and construction}

The technical knowledge for these systems was initially provided by retired government officials living in the community ${ }^{23}$ and individuals with relations to the white large-scale farmers in the region. ${ }^{24}$ This know-how was then disseminated by artisans among themselves. Plantation owners sporadically supported the construction of these schemes by supplying old pipes and storage tanks. ${ }^{25}$ The proximity to the plantations also ensured access to suppliers of material, while local shop owners also assisted with technical advice. ${ }^{26}$

With the exception of the one private supply scheme, where users joined gradually and paid a connection fee, every household would initially contribute 25-150 USD for the construction (depending on the construction cost and number of members joining). In addition, every household had to deploy one member (or hire someone) to help with construction or cooking on the dedicated construction days. ${ }^{27}$ The initial meetings were open to all households within the planned service area, but not everyone joined the schemes. The main reasons for not joining were that they had access to public water services ${ }^{28}$, that they did not trust the plan to be successful and therefore did not want to risk the expenditure ${ }^{29}$ or that they could not afford to join. ${ }^{30}$ Another group of community members contributed to the construction of schemes and installed pipes to their homesteads, but due to technical issues never received any water. ${ }^{31}$ The rules to join schemes at a later stage differ. In one scheme, it was decided that no one can join later, limiting access to the initial users ${ }^{32}$. In three schemes, users could still join by paying a fee and purchasing the materials needed ${ }^{33}$. In two other schemes, service levels were so low that no additional users wanted to join. ${ }^{34}$

All described schemes are using (high-density) polyethylene pipes connected to a water abstraction point at a spring or small river upstream (see Fig. 2) of the served area (see Fig. 3). In all schemes, each member has an individual water tap at household level connected to the main distribution network. Only 4 out of the 6 studied schemes collect the water in storage tanks before distribution (see Fig. 4), enabling the operator to store water and increase the pressure during times of high consumption. Additional filters at such tanks help reduce sediments entering the piped network. In one scheme, the operator also regularly adds chlorine overnight to the tank to purify the water. ${ }^{35}$

None of these systems can provide services to all users simultaneously. The services in some schemes are therefore irregular, while others have agreed on rotation schedules and one even has a written agreement that guarantees its users access to water every third day. ${ }^{36}$ The fact that water services are often not available on a daily basis has led to individual investments into storage capacity at household level. A household survey conducted by IWMI showed that the average storage capacity in the village amounts to 951 litres per household (Van Koppen, 2017).

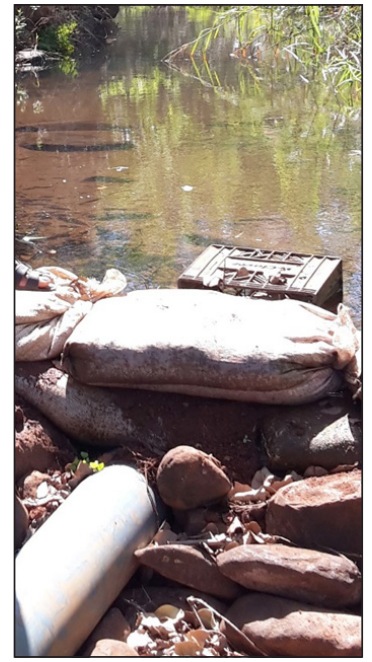

Figure 2. Water abstraction point Mulangapuma 2

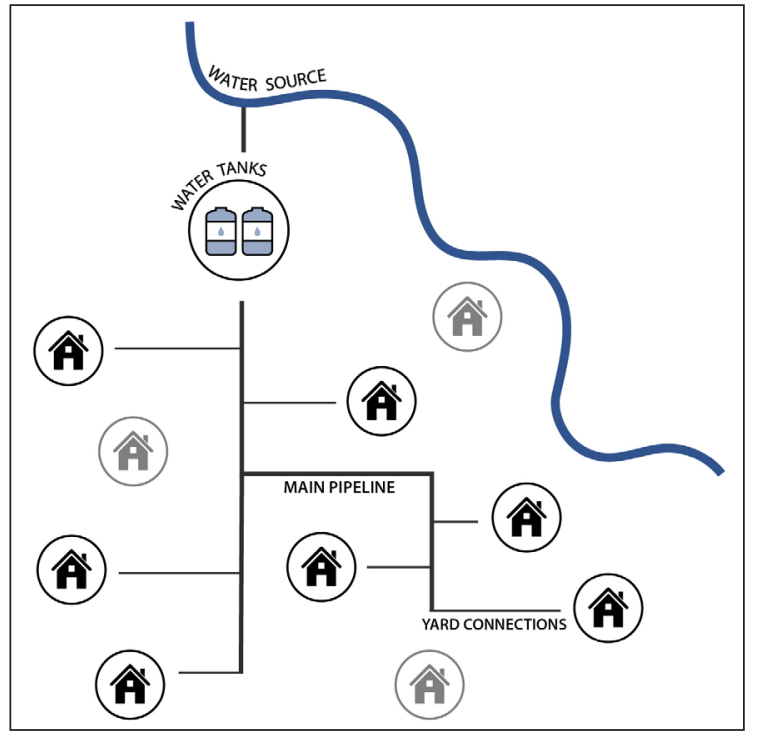

Figure 3. Sketch of the generic setup of the local self-supply schemes

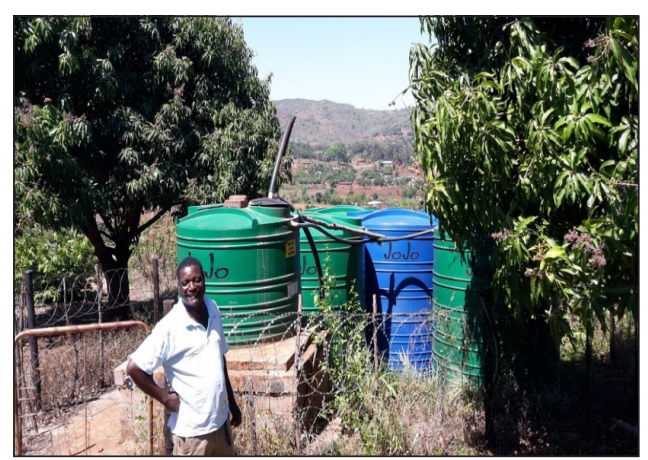

Figure 4. Storage tanks Mulangapuma 1 


\section{Operation and maintenance}

In three schemes, the right to water services, established through initial contributions in funding and labour, has to be renewed through a fixed monthly payment of 1.5-3.5 USD for operation and maintenance. Users pay either at a meeting or directly to the chairperson. ${ }^{37}$ In one scheme, this money is being kept in a collective bank account to pay the operator a fixed stipend ${ }^{38}$. In two other cases, the full amount is given to the operator(s) who in turn take(s) care of the maintenance. ${ }^{39}$ In one of the latter cases, there is a written rule that receipts of expenditures are to be collected, since accountability over the use of these funds is considered key to keeping a good paying morale. In the private scheme, the owner collects the fee and takes care of the operation and maintenance himself. ${ }^{40}$ One scheme that used to collect fees had to stop collecting, since the former operator allegedly misused funds. ${ }^{41}$ While this occurred 2 years before, the scheme's chairperson stated that insufficient trust had been gained for users to resume payments. In this and one more scheme, the operator(s) work voluntarily and users only contributed money when special meetings were called to address issues. ${ }^{42}$ In a third scheme, the users have to organise solutions for issues themselves. ${ }^{43}$ All systems with regular payments agreed to either fine $e^{44}$ or disconnect households that fail to pay. ${ }^{45}$ They enforce this, since they share the notion that a lack of sanctions has a very negative influence on the payment morale of their users. ${ }^{46}$

Operational tasks focus primarily on opening and closing of valves and implementation of rotation schedules. Common maintenance tasks concern replacing leaking pipe sections and cleaning of the water intake, water filters and storage tanks. ${ }^{47} \mathrm{In}$ schemes without regular meetings, users expressed dissatisfaction with the lack of coordination to tackle problems ${ }^{48}$, which can lead to lengthy breaks in service delivery. In two schemes, this even led to permanent breakdowns for some households. ${ }^{49}$

\section{Forming institutions}

The relevance of the local leaders is not only manifested in their approval for forming four of these schemes, but also in the fact that these schemes usually cover the area of influence of one headman..$^{50}$ One of the two exceptions to this was set up with the approval of the traditional authorities but is based on an existing burial society and therefore includes community members with different local leaders. ${ }^{51}$ The other exception is the private scheme, which was initially started as a private water supply to one household and then grew over the years, crosscutting various traditional leaders. ${ }^{52}$

These first meetings of the communal schemes were in three cases initiated by an individual ${ }^{53}$ and in two cases by a group of community members, who subsequently took a lead in the planning and construction of the infrastructure. While none of the schemes has an officially recognised structure, the community members that took responsibility are often known by community members and they are referred to as the committee (also in this article) (Van Koppen, 2017).

At the time of the interviews, only two schemes were holding regular/frequent meetings (every month ${ }^{54}$ and on several occasions per year ${ }^{55}$ ) and only one of them had a written collation of their normative system that could be considered as a constitution. ${ }^{56}$ The three other communal schemes only met ad hoc when problems occurred. ${ }^{57}$ One of these bigger schemes did not hold a user meeting since it had finalised construction 4 years earlier, ${ }^{58}$ despite users facing challenges in service provision. While the voluntary operator in one scheme is responsive, users in two of these schemes expressed dissatisfaction with the uncertainty about who is in charge of calling such meetings. ${ }^{59}$
When problems emerge, the committee members try to mediate. In cases where the issue cannot be resolved or involves members of the committee, it is taken to the traditional authorities. ${ }^{60}$ While the role of traditional leaders in the resolution of conflicts among users is recognised, it can be problematic. Affected water users can find it difficult to raise issues publicly or accuse someone that they perceive as more powerful of wrongdoing. An example for this is how in one of the schemes a whole group of tail-end users during interviews accused another user of cutting the connection to their area in an attempt to increase the water pressure at his house. They refused to raise this point publicly though, since the accused community member is known to be a master of black magic. ${ }^{61}$ An advisor to the traditional leader is aware of the existence of such issues, but said that the traditional leader would only be able to act on such accusations, once they had been raised in a community meeting. ${ }^{62}$ This reluctance to call on traditional leaders to resolve issues opens room for more powerful actors to dominate.

There is one scheme, which is not operating through collective action, but functions like a private service provider. The main pipelines belong to one individual and for a connection fee, households can connect to this system. ${ }^{63}$ Each household then pays a monthly fee for the water services provided. Issues with service delivery are being reported directly to the owner, who addresses them personally.

\section{Performance assessment \\ Coverage, service level and reliability}

While these schemes are open to everyone ${ }^{64}$, an initial investment is required to join and in some schemes, the users are asked to contribute each month. Hence, users that are not willing or able to make these contributions are being excluded. This is a major difference to public schemes that are built to serve all community members. Such user contributions also contradict the free basic water policy of 2001, in which each South African has a right to 25 litres of water per day free of charge (Muller, 2008).

The service levels vary not only between schemes, but also between head and tail-end users within the same scheme. While some users are receiving reliable and predictable services (every day or three times per week), others receive water irregularly and only once or twice a week. Increasing the storage capacity at household level is a common strategy to cope with this variability, but again demands investments, which negatively affects access for poor households. A lack of expertise leads to technical shortcomings as manifested by some households having invested but never receiving any water. ${ }^{65}$

\section{Governance and accountability}

The emerging institutions for self-supply were primed on existing social structures, especially the traditional leaders. In most cases, the latter provided the platform for their emergence and they remain important for conflict resolution. The example above shows that such a reliance on traditional authorities potentially reinforces existing power structures, inviting clientelism and exclusion of marginalised community members.

The strength of the governance structures and accountability relations created differs greatly between the schemes. This becomes clear when looking at the way breakdowns are handled. Not in all schemes is it clear to users who should be contacted in such instances. In those cases where users were contributing monthly, fewer or no complaints about the responsiveness of the operator and management were raised. This shows that strong accountability relations can emerge in self-supply schemes and suggests that user contributions strengthen these relationships. Yet, even in schemes that are owned and partly constructed by users, many users do not know how to repair broken infrastructure, nor do they feel responsible for it. 


\section{Water quality}

While policy makers raised concerns about water quality, for the interviewees at scheme level it is of no great concern. Filtering at the level of the source is common in all schemes, but only in one scheme is chlorine regularly applied to improve water quality. According to the national norms and standards for domestic water, all water provided to users should be tested with 'the frequency of testing depending on the size of the community' (DWS, 2017 p. 15), but in none of the schemes is such water testing taking place. Yet, water quality is a main concern for officials when considering the recognition of self-supply initiatives. ${ }^{66}$

\section{DISCUSSION}

This paper shows that community members are capable and willing to take an active role in service delivery. They organise, invest and fill gaps, thus expanding coverage of water supply. At the same time, it is important not to romanticise these community-owned schemes. The described examples suggest that such schemes can be an incremental step to improve access to services, but none of the schemes, in their current form, provide services according to the prevailing national standards. This is due to the fact that community members who cannot or do not want to contribute financially do not receive services. Moreover, traditional institutions reinforce existing power balances to the disadvantage of the marginalised and there is no monitoring of the water quality.

Still, we believe community members could become more central in service delivery. Pathways could be explored to create support services for existing self-supply schemes in order to attain higher service levels. Ideally, the willingness of users to get involved in service delivery would receive recognition in the public approach. In the conclusion we raise some pertinent issues related to this.

\section{CONCLUSION}

While the results presented above indicate the capacities and willingness of community members to take responsibility for water service delivery, this analysis is only a first step. We identify two fields that could be further investigated: support services for self-supply and potential applications of these lessons in conventional public service delivery. For the development of support services, Sutton et al (2021) propose to first study the efforts of community members, then pilot support services and develop a policy/strategy, before upscaling it. Such an approach could help to evaluate if support services will enable self-supply schemes to overcome the issues related to coverage, equality and water quality, in order to fulfil the national service standards. Only in that case will self-supply become a valuable approach to public service delivery in South Africa. As described by Galvin (2015) in a sanitation context, such community-owned solutions should not become a way for the wealthy of South Africa to abrogate their responsibilities and commitments.

We see collaboration between municipalities and users as a more feasible path to improving public service delivery. To elaborate this potential, we propose a form of prototyping similar to the approach of Sutton et al. (2021) introduced above. Public infrastructure grants can, for example, only be used to build street taps (Hofstetter et al., 2020): would it be possible to work with users and enable them to extend the basic public infrastructure to add household connections? Or, could the strict regulations preventing community organisations from getting involved in operation and maintenance be adapted to allow for comanagement where this is feasible and in the interest of the users? And how can approaches like the one described in Hofstetter et al. (2020) that aim to improve the influence of communities in the planning and construction of new infrastructure be integrated into public service delivery? ${ }^{67}$ South Africa is unique in recognizing access to water as a constitutional right: it would be ironic if such legal recognition leads to the stifling of initiatives from citizens and communities to extend the coverage of drinking water supply.

\section{ACKNOWLEDGMENTS}

This study was a contribution by the International Water Management Institute to the diagnostic phase of the project 'Operationalizing community-driven water services for multiple uses' supported by the African Water Facility and implemented by the Water Research Commission of South Africa. We would like to thank all the interviewees who took the time to answer our questions and made this study possible.

\section{REFERENCES}

ADVANI R (2010) Using market finance to extend water supply services in peri-urban and rural Kenya. International Finance Corporation (World Bank Group), Washington DC, USA.

ARVONEN V, KIBOCHA SN, KATKO TS and PIETILÄ P (2017) Features of water cooperatives: A comparative study of Finland and Kenya. Public Works Manage. Polic. 22 (4) 356-377. https://doi. org/10.1177/1087724X17715267

BERMAN PS (2007) Global legal pluralism. S. Calif. Law Rev. 80 11551238.

BOELENS R and DOORNBOS B (2001) The battlefield of water rights: rule making amidst conflicting normative frameworks in the Equadorian highlands. Human Org. 60 (4) 343-355. https://doi. org/10.17730/humo.60.4.d3v194qmcael7ett

BOELENS R and VOS J (2014) Legal pluralism, hydraulic property creation and sustainability: The materialized nature of water rights in user-managed systems. Curr. Opin. Environ. Sustainability. 11 55-62. https://doi.org/10.1016/j.cosust.2014.10.001

BOELENS R and ZWARTEVEEN M (2005) Prices and politics in Andean water reforms. Dev. Change. 36 (4) 735-758. https://doi. org/10.1111/j.0012-155X.2005.00432.x

BURMAN J (1969) Who Really Discovered South Africa? Human \& Rousseau Publishers, Cape Town. 170 pp.

BUTTERWORTH J, ADANK M, BAKKER-KRUIJNE E, MEKONTA L and KLAASSEN I (2014) IRC: Guidelines for developing a selfsupply acceleration plan for your area. IRC, Delft.

BUTTERWORTH J, SUTTON S and MEKONTA L (2013) Self-supply as a complementary water services delivery model in Ethiopia. Water Alt. 6 (3) 405-423.

CARTER R (2006) Investigating Options for Self-help Water Supply. RWSN, Nairobi.

CLEAVER F (2001) Institutional bricolage, conflict and cooperation in Usangu, Tanzania. IDS Bull. 32 (4) 26-35. https://doi.org/10. 1111/j.1759-5436.2001.mp32004004.x

CLEAVER F (2002) Reinventing institutions: Bricolage and the social embeddedness of natural resource management. Eur. J. Dev. Res. 14 (2) 11-30. https://doi.org/10.1080/714000425

CLEAVER F (2017) Development through Bricolage. Routledge, Abingdon, UK. 219 pp.

CLEAVER F and DE KONING J (2015) Furthering critical institutionalism. Int. J. Commons. 9 (1) 1-18. ttps://doi.org/10.18352/ijc.605

COWARD WE (1986a) Direct or indirect alternatives for irrigation investment and the creation of property. In: Easter KW (ed.) Irrigation Investment, Technology and Management Strategies for Development. Westview Press, Boulder and London.

COWARD WE (1986b) State and locality in Asian irrigation development: the property factor. In: Nobe KC and Sampath RK (eds) Irrigation Management in Developing Countries: Current Issues and Approaches. Westview Press, Boulder and London.

CRANFIELD UNIVERSITY; AGUACONSULT; IRC (2006) Landscaping and review of approaches and technologies for water, sanitation and hygiene: opportunities for action. Main Report. Cranfield University; Aguaconsult; IRC, Delft.

DAGADA MC, NESAMVUNI AE, TSHIKOLOMO KA, VAN ROOYEN J and STROEBEL A (2015) Factors Influencing fruit profitability at Tshakhuma and Khumbe Markets, Limpopo Province, South Africa. J. Agric. Sci. 7 (7) 53-63. https://doi.org/10.5539/jas.v7n7p53 
DANN P and SATTELBERGER J (2015) The concept of accountability in international development co-operation. In: Development CoOperation Report 2015: Making Partnerships Effective Coalitions for Action. OECD Publishing. Paris, France.

DE KONING J (2011) Reshaping institutions: bricolage processes in smallholder forestry in the Amazon. PhD thesis, Wageningen University.

DE KONING J (2014) unpredictable outcomes in forestry - governance institutions in practice. Soc. Nat. Resour. 27 (4) 358-371. https://doi. org/10.1080/08941920.2013.861557

DE WIT J and AKINYOADE A (2008) Working Paper Accountability in Formal and Informal Institutions: A cross country analysis. Working Paper 464. Institute of Social Studies (ISS), The Hague.

DWS (Department of Water and Sanitation, South Africa) (2017) National norms and standards for domestic water and sanitation services. Department of Water and Sanitation, Pretoria

DPLG (Department of Provincial and Local Government, South Africa) (2000) White Paper on Municipal Services Partnerships. DPLG Pretoria.

DWAF (Department of Water Affairs and Forestry, South Africa) (1994) White paper on water supply and sanitation policy. Pretoria, South Africa.

DWAF (Department of Water Affairs and Forestry, South Africa) (2000a) Izingolweni community based water services provider case study Ugu regional council. Pretoria, South Africa.

DWAF (Department of Water Affairs and Forestry, South Africa) (2000b) Makhosini community based water services provider case study Zululand Regional Council. Pretoria, South Africa.

DWAF (Department of Water Affairs and Forestry, South Africa) (2000c) Nzimakwe water services provider case study Ugu Regional Council. Pretoria, South Africa.

DWAF (Department of Water Affairs and Forestry, South Africa) (2000d) Peddie rural villages Cisira, Ncala, Mgwangqa and water services provision utilising a community-based structure. Pretoria, South Africa.

DWAF (Department of Water Affairs and Forestry, South Africa) (2000e) Rooiboklaagte community based water services provider case study. Pretoria, South Africa.

DWAF (Department of Water Affairs and Forestry, South Africa) (2002) guidelines for compulsory national standards and norms and standards for water services tariffs. Pretoria, South Africa.

DWAF (Department of Water Affairs and Forestry, South Africa) (2004) A history of the first decade of Water Service delivery in South Africa 1994 to 2004. Pretoria, South Africa.

EALES K (2011) Water services in South Africa 1994-2009. In: Schreiner B and Hassan R (eds) Transforming Water Management in South Africa: Designing and Implementing a New Policy Framework. Springer Science and Business Media, Heidelberg.

FAO (2018) WaPOR. URL: https://wapor.apps.fao.org/home/1?lat=-30. 559482\&lon=22.937506 (Accessed 14 June 2019).

FEDERAL DEMOCRATIC REPUBLIC OF ETHIOPIA (2012) National policy guidelines for self-supply in Ethiopia. Federal Democratic Republic of Ethiopia, Addis Ababa, Ethiopia.

GALVIN M (2015) Talking shit: is Community-Led Total Sanitation a radical and revolutionary approach to sanitation? WIRE's Water. 2 9-20. https://doi.org/10.1002/wat2.1055

GELHARD M (2014) WASH self-supply in Sierra Leone: perspectives and options. Welthungerhilfe and Wateraid, Bonn, Germany.

GLOWS (2012) Learning about self-supply. IRC, Addis Ababa.

GOUWS C, MOEKETSI I, MOTLOUNG S, VAN GREUNING G and VAN ZYL L (2010) SIBU and the crisis of water service delivery in Sannieshof, North West Province. J. Transdisc. Res. South. Afr. 6 (1) 25-56. https://doi.org/10.4102/td.v6i1.123

GRÖNWALL J (2016) Self-supply and accountability: to govern or not to govern groundwater for the (peri-) urban poor in Accra, Ghana. Environ. Earth Sci. 75 (16) 1-10. https://doi.org/10.1007/s12665-0165978-6

HALL K, CLEAVER F, FRANKS T and MAGANGA F (2014) capturing critical institutionalism: a synthesis of key themes and debates. Eur. J. Dev. Res. 26 (1) 71-86. https://doi.org/10.1057/ejdr.2013.48

HOFSTETTER M, BOLDING A and VAN KOPPEN B (2020) Addressing failed water infrastructure delivery through increased accountability and end-user agency: The case of the Sekhukhune District, South Africa. Water Alt. 13 (3) 843-863.
JUUTI PS, MÄKI HRJ and WALL K (2007) Water supply in the Cape settlement from the mid- $17^{\text {th }}$ to the mid $-19^{\text {th }}$ centuries. In: Juuti PS, Katko TS and Vuorinen HS (eds) Environmental History of WaterGlobal Views on Community Water Supply and Sanitation. IWA Publishing, London, UK.

KOMAKECH HC, CONDON M and VAN DER ZAAG P (2012) The role of statutory and local rules in allocating water between largeand small-scale irrigators in an African river catchment. Water SA. 38 (1) 115-126. https://doi.org/10.4314/wsa.v38i1.14

KYEYUNE S, KIYIMBA J, ATUHAIRWE S, KIWANUKA J, SERUWO M, NANGENDO L, MAGARA P, SATYA ALI C and BAZIWE D (2011) Self supply: experiences in Uganda: a compilation of the case studies on self supply presented at the $3^{\text {rd }}$ National Learning Forum-City Royal Hotel, December 5 - 6, 2011. Ministry of Water and Environment. Kampala, Uganda.

MACCARTHY MF, ANNIS JE and MIHELCIC JR (2013) Unsubsidised self-supply in eastern Madagascar. Water Alt. 6 (3) 424-438.

MAIGA H, MAIGA B and SUTTON S (2006) Self-supply in Mali. Waterlines. 25 (1) 13-14. https://doi.org/10.3362/0262-8104.2006.034

MÄKI HRJ (2007) Development of the supply and acquisition of water in South African towns in 1850-1920. In: Juuti PS, Katko TS and Vuorinen HS (eds) Environmental History of Water-Global Views on Community Water Supply and Sanitation. IWA Publishing, London.

MALTHA A and VELDMAN R (2016) A market-based approach to scale up sustainable rural water supply: experiences from Tanzania. In: Proceedings of the $39^{\text {th }}$ WEDC International Conference, 11- 15 July 2016. Kumasi, Ghana.

MANIKUTTY S (1997) Community participation: so what? Evidence from a comparative study of two rural water supply and sanitation projects in India. Development policy review. J. Overseas Dev. Inst. 15 (2) 115-140. https://doi.org/10.1111/1467-7679.00029

MARCATELLI M and BÜSCHER B (2019) Liquid violence: the politics of water responsibilisation and dispossession in South Africa. Water Alt. 12 (2) 760-773.

MARKS SJ and DAVIS J (2012) Does user participation lead to sense of ownership for rural water systems? Evidence from Kenya. World Dev. 40 (8) 1569-1576. https://doi.org/10.1016/j.worlddev.2012.03.011

MATEBESI S (2017) Civil Strife Against Local Governance. Barbara Budrich Publishers, Opladen, Berlin, Toronto. 184 pp.

MAY A (2004) The withholding of rates in five local municipalities. Community Law Center, Cape Town.

MEINZEN-DICK RS and PRADHAN R (2001) Implications of legal pluralism for natural resource management. IDS Bull. 32 (4) 10-17. https://doi.org/10.1111/j.1759-5436.2001.mp32004002.x

MERRY S (1988) Legal pluralism. Law Soc. Rev. 22 (5) 869-896. https:// doi.org/10.2307/3053638

MULLER H, MULLER M, MACLEOD N, PALMER I and SCHOEMAN G (2017) Africa, WASH and the millennium development goals: A local systems case study of how South Africa achieved goal 7c. USAID, Washington DC.

MULLER M (2008) Free basic water - a sustainable instrument for a sustainable future in South Africa. Environ. Urban. 20 (1) 67-87. https://doi.org/10.1177/0956247808089149

MVULA TRUST (2000) Developing community-based monitoring \& evaluation tools for the rural water supply and sanitation projects. Mvula Trust, Midrand.

NATIONAL TREASURY, SOUTH AFRICA (2011) Local Government Budgets and Expenditure Review: 2006/7 - 2012/13. Pretoria, South Africa.

NJOH A (2009) Self-help, a viable non-conventional urban public service delivery strategy: lessons from Cameroon. UN-Habitat, Nairobi.

NKOKA F, VELDWISCH GJ and BOLDING A (2014) Organisational modalities of farmer-led irrigation development in Tsangano District, Mozambique. Water Alt. 7 (2) 414-433.

NYARKO KB, DWUMFOUR-ASARE B, APPIAH-EFFAH E and MORIARTY P (2010) Cost of delivering water services in rural areas and small towns in Ghana. In: IRC Symposium 2010: Pumps, Pipes and Promises, 16-18 November 2010. The Hague, the Netherlands.

OLSCHEWSKI A, MATIMATI R and WATERKEYN A (2016) Review of Upgraded Family Well Programme in Makoni \& Buhera districts, Manicaland Province, Zimbabwe Country Report. UNICEF and SKAT Foundation, St. Gallen, Switzerland. 
OLSCHEWSKI A, SUTTON S and NGOMA M (2017) Review of selffinanced Water supply in Milenge district, Zambia. UNICEF and Skat foundation, St. Gallen, Switzerland.

OLUWASANYA G, SMITH J and CARTER R (2011) Self-supply systems: Urban dug wells in Abeokuta, Nigeria. Water Sci. Technol. Water Suppl. 11 (2) 172-178. https://doi.org/10.2166/ws.2011.026

OOMEN T (2021) Hydroterritorial reconfiguration in the context of Cape Town's Day Zero Water Crisis. Masters thesis, Wageningen University.

ORANJE M and VAN HUYSSTEEN E (2011) Nestling national 'transformation' imperatives in local 'servicing' space: Critical reflections on an intergovernmental planning and implementation project. Town Regioal Plann. 58 6-16.

OSTROM E (1993) Design principles in long-enduring irrigation institutions. Water Resour. Res. 29 (7) 1907-1912. https://doi.org/ 10.1029/92WR02991

PIMENTEL D (2011) Legal pluralism in post-colonial Africa: linking statutory and customary adjudication in Mozambique. SSRN Electron. J. 14 (1) 59-104. https://doi.org/10.2139/ssrn.1668063

PUMP AID (2016) Kasungu self-supply pilot project. Pump Aid, Lilongwe.

RSA (Republic of South Africa) (1997) Water Services Act. Act No. 108 of 1997. Government Printer, Pretoria.

RSA (Republic of South Africa) (1998a) White Paper on Local Government. Government Printer, Pretoria.

RSA (Republic of South Africa) (1998b) National Water Act. Act No. 36 of 1998. Government Printer, Pretoria.

RSA (Republic of South Africa) (2000) Municipal Systems Act. Act No. 32 of 2000. Government Printer, Pretoria.

SANCHEZ LMSN, KEMERINK-SEYOUM JS and ZWARTEVEEN M (2019) Water infrastructure always in-the-making: Distributing water and authority through the water supply network in Moamba, Mozambique. Water. 11 (9) 1926-1943. https://doi.org/10.3390/ w11091926

SCHREINER B and VAN KOPPEN B (2002) Catchment Management Agencies for poverty eradication in South Africa. Phys. Chem. Earth. 27 969-976. https://doi.org/10.1016/S1474-7065(02)00100-6

SIERRA LEONE (2013) Rural Water Supply and Small Towns - Strategy Document. Sierra Leone Ministry of Water Resources, Freetown.

SIMPSON NP, SHEARING CD and DUPONT B (2019) Climate gating: A case study of emerging responses to Anthropocene Risks. Clim. Risk Manage. 26 (April) 1-10. https://doi.org/10.1016/j. crm.2019.100196

SIMPSON NP, SIMPSON KJ, SHEARING CD and CIROLIA LZ (2019) Municipal finance and resilience lessons for urban infrastructure management: a case study from the Cape Town drought. Int. J. Urban Sustainable Dev. 1-20. https://doi.org/10.1080/19463138.201 9.1642203

STATS SA (Statistics South Africa) (2017) The state of basic service delivery in South Africa: In-depth analysis of the Community Survey 2016 data. Statistics South Africa, Pretoria.

STATS SA (Statistics South Africa) (2019) General Household Survey 2017. Statistics South Africa, Pretoria.

SUTTON S (2004) Preliminary desk study of potential for self-supply in sub-Saharan Africa. Wateraid and Rural Water Supply Network, St Gallen, Switzerland.
SUTTON S (2007) Report on Ethiopia self supply initiatives and potential: Based partly on Experiences from Waliso, Becho and Ilu Woredas, Oromia Region. Rural Water Supply Network, St. Gallen, Switzerland.

SUTTON S (2018) Self-supply - a cost-effective rural water option for the hard to reach. SWL Consultants, Shrewsbury, UK.

SUTTON S and BUTTERWORTH J (2021) Self-Supply. Practical Action Publishing, Warwickshire, UK.

SUTTON S, LANE J, HONES J, BAUMANN E, NARKEVIC J and CROSS P (2004) Self Supply: A Fresh Approach to Water for Rural Populations. WSP, RWSN and DFID, Nairobi.

TAING L, CHANG CC, PAN S, ARMITAGE NP and TAING L (2019) Towards a water secure future : reflections on Cape Town's Day Zero crisis. Urban Water J. 16 (7) 530-536. https://doi.org/10.1080/15730 62X.2019.1669190

TODES A (2004) Regional planning and sustainability: Limits and potentials of South Africa's integrated development plans. J. Environ. Plann. Manage. 47 (6) 843-861. https://doi.org/10. 1080/0964056042000284866

TSHITANGONI M and FRANCIS J (2016) Pillars of resilience of traditional leadership in Vhembe District of Limpopo Province. J. Soc. Sci. 46 (3) 241-250. https://doi.org/10.1080/09718923.2016.1 1893532

VAN DER WALDT G (2014) Infrastructure project challenges: the Case of Dr Kenneth Kaunda District Municipality. J. Construct. Project Manage. Innov. 4 (1) 844-862.

VAN KOPPEN B (2017) Water Assessment Baseline Tshakhuma. IWMI, Pretoria. 24 pp.

VAN KOPPEN B and JHA N (2005) Redressing racial inequities through water law in South Africa, Interaction and contest among legal frameworks. In: Roth D, Boelens R and Zwarteveen M (eds) Liquid Relations: Contested Water Rights and Legal Complexity. Rutgers University Press, New Brunswick, New Jersey, and London.

VAN KOPPEN B, HOFSTETTER M, NESAMVUNI E, CHILUWE Q (2020) integrated management of multiple water sources for multiple uses: rural communities in Limpopo Province, South Africa. Water SA. 46 (1) 1-11. https://doi.org/10.17159/wsa/2020.v46.i1.7870

VON BENDA-BECKMANN F (2002) Who's afraid of legal pluralism? J. Legal Pluralism Unofficial Law. 34 (47) 37-82. https://doi.org/10.10 80/07329113.2002.10756563

STILL D and BALFOUR F (2006) The use of key performance indicators in the benchmarking of rural water supply schemes: an aid to the development of meaningful local government capacity. WRC Report No. 255/06. Water Research Commission, Pretoria. 155 pp.

CSIR (2020) Legal and institutional barriers to community owned water supply schemes. Draft report for Deliverable 4 of WRC project no. K5-2922. Water Research Commission, Pretoria. 104 pp.

WORLD BANK (2003) World Development Report 2004: Making Services Work for Poor People. World Bank and Oxford University Press, Wahington DC, USA. $271 \mathrm{pp}$

WHO (World Health Organization) (2017) Financing universal water, sanitation and hygiene under the sustainable development goals: GLAAS 2017 Report. WHO, Geneva. 96 pp.

YACOOB M (1990) Community self-financing of water supply and sanitation: What are the promises and pitfalls? Health Polic. Plann. 5 (4) 358-366. https://doi.org/10.1093/heapol/5.4.358 
${ }^{1}$ Interviews with two former high-ranking officials of DWAF 19.5. 18/20.5.18 and an experienced water sector consultant 10.5.18

${ }^{2}$ 'Water-services authority means any municipality, including a district or rural council as defined in the Local Government Transition Act, 1993 (Act No. 209 of 1993) responsible for ensuring access to water services' (Republic of South Africa, 1997, p. 10).

${ }^{3}$ 'Water services provider means any person who provides water services to consumers or to another water services institution, but does not include a water services intermediary' (Republic of South Africa, 1997, p. 10).

${ }^{4}$ Discussion with a high-ranking official of the Municipal infrastructure Grant (MIG) 21.3.18.

${ }^{5}$ Interviews with two former high-ranking officials of the Department for Water Affairs and Forestry, that were involved in the negotiations of the new policies: 20.5.18/19.5.18.

${ }^{6}$ Interviews with two former high-ranking officials of the DWAF 20.5.18/28.9.18, an experienced water sector consultant 26.3.18/ Water Research Commission (2021).

${ }^{7}$ Interviews with two planning engineers of a (rural) district municipality in Limpopo province 19.9.18/21.9.18, the director of the water service department of a (rural) local municipality 11.12.17.

${ }^{8}$ Interviews with the mayor of a (rural) district municipality in Limpopo province 20.9.18, a high-ranking official of the Department of Water and Sanitation (DWS) Limpopo 20.9.18, a high ranking official of the extended public works program Limpopo 27.9.18.

${ }^{9}$ Interviews with the municipal manager of a (rural) district municipality in Limpopo province 21.9.18, the head of the project implementation unit of a (rural) district municipality in Limpopo province 21.9.18.

${ }^{10}$ IDP's assist with the need identification and budget allocation prior to the actual act of service delivery. Earlier studies showed that IDP's only have a limited influence on the budget allocation (Hofstetter et al., 2020; Todes, 2004; Oranje and van Huyssteen, 2011; van der Waldt, 2014).

${ }^{11}$ Interviews with two water project managers of a (rural) district municipality in Limpopo province 19.9.18/20.9.18, the deputy director of the department of water supply in a (rural) district municipality in Limpopo province 21.9.18, a leading engineer of a (rural) district municipality in Limpopo province 5.12.17.

${ }^{12}$ It is generally unclear, if uses to create an income can also be considered as such so called Schedule One uses (van Koppen and Jha, 2005) and there have been calls to clarify the definition of Schedule One uses and to include such small scale productive uses (Schreiner and van Koppen 2002).

${ }^{13}$ Discussions with a high-ranking official of the Municipal infrastructure Grant (MIG) 21.3.18, an experienced water sector consultan 26.3.18, a high-ranking official at the Water Resource Commission WRC 28.3.18.

${ }^{14}$ According to section 102(2) of the municipal systems act (Republic of South Africa, 2000), the municipality is not allowed to collect depth from any citizen in case there is a dispute over the specific amount.

15 'Operationalizing community-driven multiple use water services (MUS) in South Africa', a project of the Water Resource Commission (WRC) of South Africa. Tshakhuma was included as case in the project on the request of a government official due to the lack of an official approach on how to interact with such self-supply initiatives.

${ }^{16}$ Interviews with a headman 9.4.18 / committee member: 9.4.18.

${ }^{17}$ van Koppen, 2017, Interview with a committee member 4.4.18 and observation of the first author.

${ }^{18}$ While in the described case all traditional leaders were male, there are also female traditional leaders in Vhembe (Tshitangoni and Francis, 2016).

${ }^{19}$ Interviews with a headman: 6.4.18, a close advisor and family member of theheadman 2.4.18, committeemembers:29.3.18/2.4.18/4.4.18/9.4.18, water users: 4.4.18a)/4.4.18b)/5.4.18/7.4.18.

${ }^{20}$ Interview with the scheme manager: 8.4.18.

${ }^{21}$ Interviews with a committee member: 2.4.18., a user: 16.4.18.
${ }^{22}$ Interviews with a committee member: 8.4.18, a traditional leader: 6.4.18.

${ }^{23}$ Interviews with a water user: 2.4 .18 , two committee members: 2.4 . 18./5.4.18, a traditional leader: 9.4.18.

${ }^{24}$ Interviews with two committee members: 29.3.18/8.4.18.

${ }^{25}$ Interviews with two committee members: 4.4.18/15.4.18.

${ }^{26}$ Interview with a committee member: 8.4.18.

${ }^{27}$ Interviews with water users: $29.3 .18 / 30.3 .18 / 2.4 .18 / 4.4 .18 / 5.4 .18 / 7.4 .18$ /2.4.18, committee members: 2.4.18/4.4.18/9.4.18, a headman: 9.4.18.

${ }^{28}$ Interviews with water users: $\left.\left.28.3 .18 / 29.3 .18 \mathrm{a}\right) / 30.3 .18 / 2.4 .18 \mathrm{a}\right) / 2.4 .18$ b)/2.4.18c)/2.4.18d)/4.4.18/5.4.18a)/5.4.18b)/5.4.18c)/5.4.18d)/6.4.18.

${ }^{29}$ Interviews with water users: 28.3.18a)/28.3.18b)/ 29.3.18/5.4.18.

${ }^{30}$ Interviews with water users: $28.3 .18 / 29.3 .18 / 6.4 .18$.

${ }^{31}$ Interviews with water users: $28.3 .18 / 31.3 .18 / 4.4 .18$ a)/4.4.18b)/4.4.18c)/ 5.4.18a)/5.4.18b)/6.4.18.

${ }^{32}$ Interviews with water users: $\left.\left.30.3 .18 a\right) / 30.3 .18 b\right)$, a committee member: 4.4.18.

${ }^{33}$ Interviews with water users: 4.4.18/5.4.18a)/5.4.18b)/6.4.18a)/6.4.18b), an operator: 5.4.18, a committee member: 5.4.18.

${ }^{34}$ Interviews with two committee members: 29.3.18/2.4.18.

${ }^{35}$ Interviews with operator: 5.4.18, committee member: 5.4.18.

${ }^{36}$ Interviews with an operator: 5.4.18, committee member: 5.4.18, written agreement seen by author: 5.4.18.

${ }^{37}$ Interviews with water users: 29.3.18/2.4.18a)/2.4.18b)/3.4.18/5.4.18a)/ 5.4.18b)/6.4.18a)/6.4.18b), an operator: 5.4.18, committee members: 4.4.18/5.4.18.

${ }^{38}$ Interviews with water users: $29.3 .18 / 30.3 .18$, a committee member: 4.4.18.

${ }^{39}$ Interviews with water users: $2.4 .18 / 3.4 .18$, a committee member: 5.4.18, an operator: 5.4.18.

${ }^{40}$ Interview with water users: 4.4.18/5.4.18a)/5.4.18b)/6.4.18a)/6.4.18b)

${ }^{41}$ Interview with a headman: 9.4.18, a committee member 9.4.18.

${ }^{42}$ Interviews with water users: $\left.30.3 .18 \mathrm{a}\right) / 30.3 .18 \mathrm{~b}$ ), a committee member: 2.4.18.

${ }^{43}$ Interviews with water users: 4.4.18/5.4.18/6.4.18a)/6.4.18b)/7.4.18/.

${ }^{44}$ Interviews with an operator: 5.4.18, a committee member: 5.4.18, written agreement seen by author: 5.4.18.

${ }^{45}$ Interviews with water users: 5.4.18/6.4.18, a headman: 6.4.18, a committee member: 30.3 .18 .

${ }^{46}$ Interviews with committee members: $5.4 .18 / 4.4 .18$, an operator: 5.4.18, a scheme manager: 8.4.18.

${ }^{47}$ Interviews with operators: $2.4 .18 / 5.4 .18 / 7.4 .18$.

${ }^{48}$ Interviews with water users: $\left.\left.\left.30.3 .18 \mathrm{a}\right) / 30.3 .18 \mathrm{~b}\right) / 4.4 .18 / 5.4 .18 / 6.4 .18 \mathrm{a}\right)$ /6.4.18b)/7.4.18/.

${ }^{49}$ Interviews with water users: $\left.\left.\left.\left.31.3 .18 / 4.4 .18 \mathrm{a}\right) / 4.4 .18 \mathrm{~b}\right) / 4.4 .18 \mathrm{c}\right) / 5.4 .18 \mathrm{a}\right) /$ 5.4.18b)/6.4.18a)/6.4.18b)/ 6.4.18c)/7.4.18

${ }^{50}$ Interviews with a headman: 6.4.18, a close advisor and family member of the headman 2.4.18, two committee members:29.3.18/ 2.4.18/4.4.18/9.4.18, water users: 4.4.18a)/4.4.18b)/5.4.18/7.4.18.

${ }^{51}$ Interviews with water users: 5.4.18/7.4.18, a committee member: 2.4.18.

${ }^{52}$ Interviews with a traditional leader: 9.4.18, observations of the leading author.

${ }^{53}$ Interviews with a community member: $2.4 .18 /$ committee members: 4.4.18/5.4.18/7.4.18, a Traditional leader: 9.4.18.

${ }^{54}$ Interviews with operator: community members:2.4.18/3.4.18, committee member: 5.4.18, operator: 5.4.18.

${ }^{55}$ Interviews with community members: $29.3 .18 / 30.3 .18$, committee member: 8.4.18. 
${ }^{56}$ Operator committee member: 5.4 .18 , committee members: 5.4 .18 , the leading author also saw the written rules and regulations that they agreed on.

${ }^{57}$ Interviews with community members: $\left.30.3 .18 / 31.3 .18 / 7.4 .18 \mathrm{a}\right) / 7.4 .1$ 8 b)/9.4.18, operator: 2.4 .18 .

${ }^{58}$ Interviews with water users: 4.4.18/5.4.18/7.4.18, committee member: 2.4.18.

${ }^{59}$ Interviews with water users: $\left.\left.\left.\left.30.3 .18 \mathrm{a}\right) / 30.3 .18 \mathrm{~b}\right) / 4.4 .18 \mathrm{a}\right) / 4.4 .18 \mathrm{~b}\right) / 5.4 .1$ 8a)/5.4.18b), former users: 5.4.18 a)/5.4.18b)/6.4.18/.

${ }^{60}$ Interview with water users: $\left.\left.29.3 .18 / 30.3 .18 \mathrm{a}\right) / 30.3 .18 \mathrm{~b}\right) / 5.4 .18, \mathrm{com}-$ mittee members: 2.4.18/ 4.4.18/7.4.18 traditional leaders: 9.4.18.

${ }^{61}$ Interviews with water users: 28.3.18/4.4.18 a)/4.4.18 b)/5.4.18/6.4.18 a) $/ 6.4 .18 b) / 6.4 .18 c)$

${ }^{62}$ Interview with an advisor to the traditional leader: 8.4.18

${ }^{63}$ Interview with water users: 4.4.18/5.4.18a)/5.4.18b)/6.4.18a)/6.4.18b)/ $6.4 .18 \mathrm{c})$.
${ }^{64}$ Interviews with water users:2.4.18/3.4.18a)/3.4.18b)/ 4.4.18a)/4.4.18b) /5.4.18a)/5.4.18b) One scheme decided not to have new members to ensure services for the initial users: water users: $30.3 .18 \mathrm{a}) / 30.3 .18 \mathrm{~b}$ ) committee member: 2.4.18/4.4.18

${ }^{65}$ Interviews with water users: $\left.\left.\left.\left.31.3 .18 / 4.4 .18 \mathrm{a}\right) / 4.4 .18 \mathrm{~b}\right) / 4.4 .18 \mathrm{c}\right) / 5.4 .18 \mathrm{a}\right) /$ $5.4 .18 b) / 6.4 .18 a) / 6.4 .18 b)$.

${ }^{66}$ Discussions with a high-ranking official of the Municipal infrastructure Grant (MIG) 21.3.18, an experienced water sector consultant 26.3.18, high-ranking official at the Water Resource Commission WRC 28.3.18

${ }^{67}$ In that article we describe a pilot project for an approach of transformative servicing that builds on a shared vision for the provision of water services in a transformed reality. It does so by focusing on enforcing end-user agency during the four phases of public service delivery: identification, planning, construction and operation. 